\title{
HOT PATENTS
}

TIGG-09/02/89-Hpa-1

MONOCLONAL ANTIBODY SPECIFIC TO LCA-BOUND HUMAN $\alpha$-FETOPROTEIN

Application number: JP87-141559 Publication number: JP88-307900

Inventor:

Yutaka Aoyagi

Yasushi Suzuki

Fumio Kimura

Naohisa Oizumi

Kenji Yoshida

Patent Claim

Monoclonal antibody could specifically recognize LCA-bound human $\alpha$-fetoprotein

Hybridoma could produce monoclonal antibody of interest thereon Example

1. From hepatocellular carcinoma patient sera, AFP purified by anti-AFP antibody column chromatography and DEAE-ion exchange chromatography. Then, purified AFP was divided into two groups, LCA-unbound and LCA-bound, by LCA (lentil lectin) column chromatography. LCA-bound AFP eluted with $0.3 \mathrm{M} \alpha$-methyl-Dglucoside from LCA Sepharose gel.

2. LCA-bound AFP, as the emulsion with FCA, injected to BALB/C mice by $i \cdot p$. shot. The splenocytes cell-fused with myeloma cells (P3U1) by $43 \%$ PEG.

3. The immunochemical properties of monoclonal antibody thereon evaluated by the reactibity to two AFP fractions, LCA-unbound and LCA-bound, immobilized onto polystyrene plate at various concentrations. The reacted antibody amount measured by use of alkaline phosphatase labelled anti-mouse Ig xenoantibodies.

Onco-developmental glycosylation have been investigated in several human tumor markers (e.g. $\gamma$-GTP, AFPetc). The sugar chain variation was pointed out by use of lectin affinity techniques. Monoclonal antibody herein shows the specificity to LCA-bound AFP, one of oncodevelopmental variants, and seems powful tool for human selological diagnosis of hepatocellular carcinoma.

(H. Matsukawa and 1. Takagahara, Oriental Yeast Co. Ltd) 
TIGG-09/02/89-Hpa-2

NEW METHODOLOGY OF MONOCLONAL ANTIBODY PREPARATION WHICH REACTS TO GLYCOLIPIDS ।

Application number: JP87-165890 Publication number: JP89-47390

Inventor:

Masahiko Yamazaki

Katsutaka Nagai

Patent Claim

New methodology, as concerning to monoclonal antibody preparation which reacts at least to $\mathrm{N}-$ glycolyl GM2 ganglioside, could be done by cell-fusion of plasmacytes from autoimmune disease animal with myeloma cells.

Example

1. Rabbit thymus membrane fraction prepared for glycolipid immunogen, emulsified with FCA, then injected into NZB mice by i.p. shot. After that, purified N-glycolyl glycolipids boosted by several ways.

2. The splenocytes cell-fused with myeloma cells (6.5.3) by $50 \%$ PEG. Hybridoma cells well-grown in HAT selected medium, Antibody of interest screened from the reactivity to $\mathrm{N}-\mathrm{glycolyl} \mathrm{GM} 2, \mathrm{~N}-$ glycolyl GM3 and IV3neuGc-nleose4Cer immobilized onto ELISA microtiter plate.

3. From the immunoblotting on TLC plate, found out monoclonal antibody specific to $\mathrm{N}-\mathrm{glycolyl}$ GM2, monoclonal antibody reacts to both $\mathrm{N}-\mathrm{glycolyl}$ GM2 and $\mathrm{N}-\mathrm{glycolyl}$ GM3. Specific antibody to N-glycolyl GM2 could not detect this glycolipid in rabbit thymus by immunoblotting technique. Subsequently, this indicates

the antibody reacts to $\mathrm{N}-\mathrm{glycolyl}$ GM2 raised autogenetically from NZB mice.

Present invention provides new methodology as concerning to monoclonal antibody reacts at least to $\mathrm{N}$-glycolyl GM2 ganglioside. This makes possible to develop monoclonal antibodies against glycolipids and to diagnose the trace amount of glycolipids in human cancer patients.

(H. Matsukawa and I. Takagahara, Oriental Yeast Co. Ltd) 
HOT FATENTS

T I GG-09/02/89-Hpa-1

抗LCA枯合性ヒト $\boldsymbol{a}$ ーフェトプロテインモノクローナル抬休

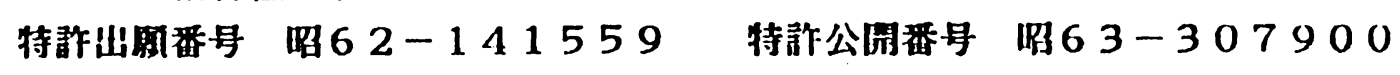

発明者出闹人

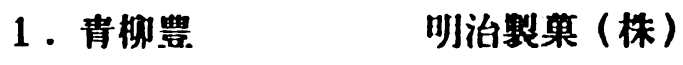

2. 跲木康史

3. 木村文男

4. 小是值久

5. 吉田触治

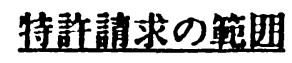

IL C A 枯合性ヒト $\boldsymbol{\alpha}$ ーフェトプロテインと特異的に枯合するモノクローナル

抗体およひモノクローナル抗体を産生するハイフリドーマ。」

実施国

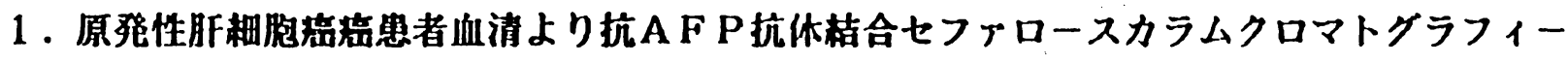
およひDEAEーセフォデックスAー50カラムクロマトクラフィーにてAFPを単一票品 にまで掅製。次いで、LCAセフェロースカラムクロマトクラフィーにてLCAカラム非枯合

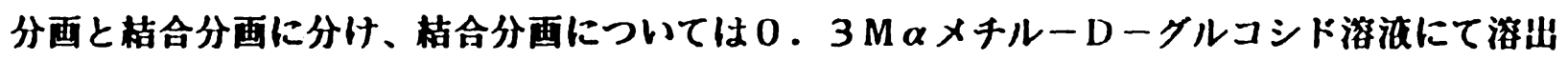
した。

2.LCA枯合性A F PをB A L B / c マウスにFCAエマルジョンとして投与。以後 1 週間间隔て

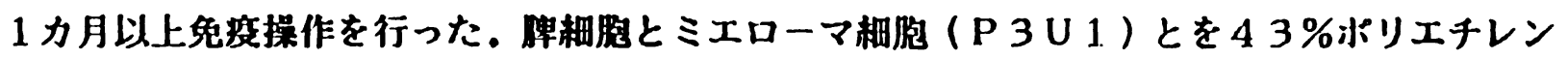
クリコールを用いて梱胞感合した。

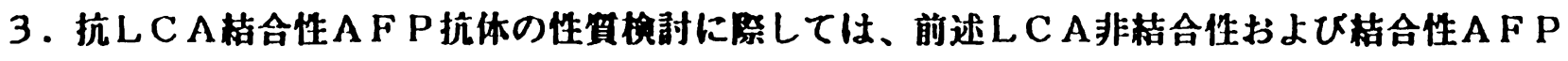
抗原を各々 96 穴平板マイクロタイタープレートに0、1、2、5、および $10 \mathrm{ug} / \mathrm{m} \mathrm{I}$

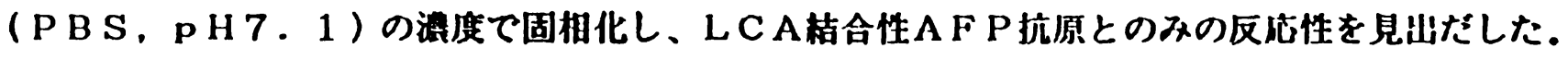
固相化抗原に枯合したモノクローナル抗体量は、アルカリフォスファターゼ票誡抗マウス抗休を 用い、各ウエルのO.D405 n mの吸光度を泪定し求めた。

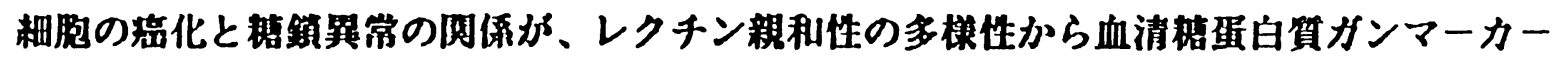

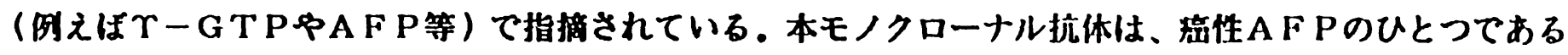

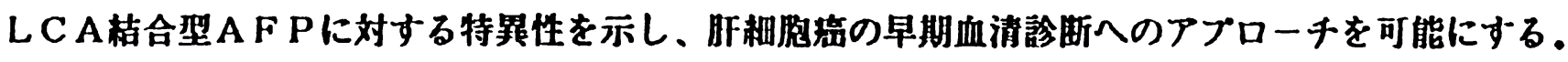
(松川博和、高河原勇、オリエンタル醉母工業、事業部生化学開発センタ一) 
HOT FATERTTS

T I G G-0 9/02/89-H pa-2 モノクローナル抗体の製道法

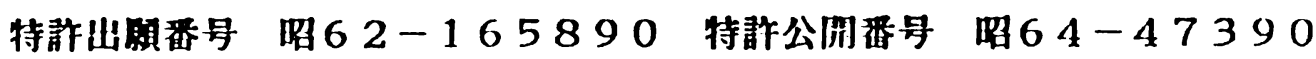

発明者出阙人

1. 山崎誠㢁 コニカ(株)

2 . 永非克寿

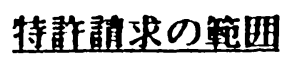

「少なくとも NークリコリルGM 2 ガンクリオシドと反志するモノクローナル抗体を、自己免疫疾患

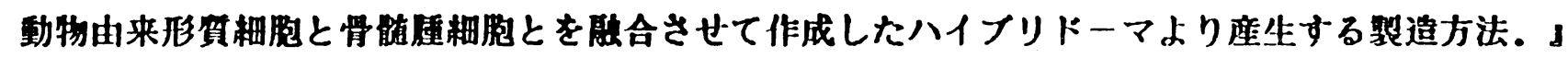
実化国

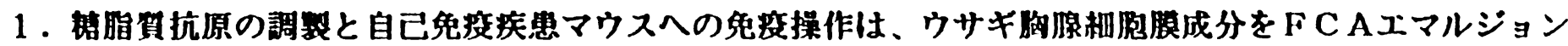
としてNZBマウスの腹成内注射することで行った。次いて、奉联 1 ては 2 週間嵝F IAを用いて同侎 に行い、更にIV 3 n e u G c - n l e Ose 4 C e r リポソームPBS海流を追加免度した。 実 2 では、䣬で処理したサルモネラミネタパクテリア80 u g に吸着させたNークリコリルGM 3

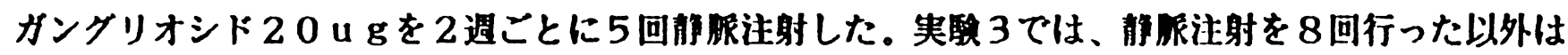
実聵 2 と同検にした。

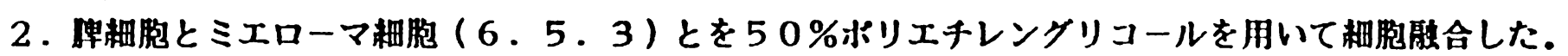
H A T睤択培地にてハイフリドーマ湅胞のみを生育させ、抗体選択は抗原としてNークリコリルGM 2 ガンクリオシド、NークリコリルGM3ガングリオシドおよひIV 3 n e u G c - n 1 e O s e 4 C e r を固相化したEL I S A用マイクロタイタープレートへの枯合性より行った。

3. TLCプレート上での i m m u n b $10 \mathrm{t}$ t i n gの枯果より、NーグリコリルGM 2 ガンクリオ シドのみ反応するモノクローナル抗休やNークリコリルGM 2 ガングリオシドおよびータリコリル GM 3ガンクリオシドと反店するモノクローナル抗体の特翼性が見山だされた。また、作製したNー

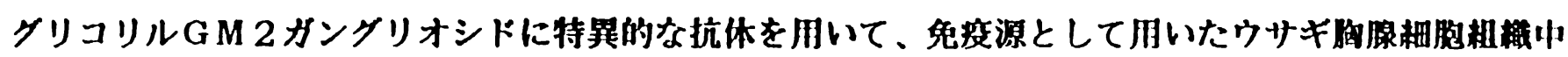
の雄脂筫を分析したところNークリコリルGM 2 ガンクリオシドの存在が碓認されず、作製した抗Nー クリコリルGM 2 ガンクリオシド活性を有するハイブリドーマ棘胞は、NークリコリルGM 2 ガンクリ オシドを抗原感作することなくN Z Bマウスより作成されたことが示された。

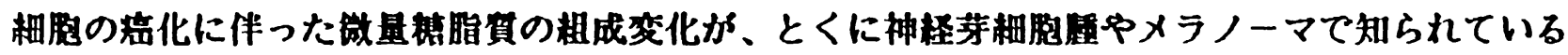

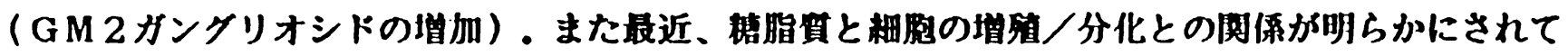
きており、今传種々の特異性を有するモノクローナル抗体を用いた各種渃脂筫分析が必要となるたろう。

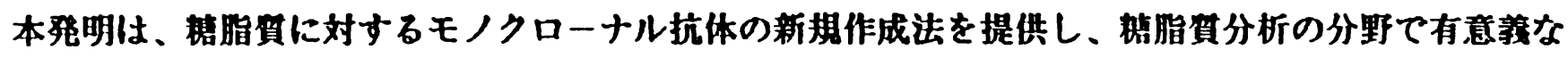
ものとなる。

(昖川博和、高河原勇、オリエンタル醅母工柴、事業部生化学開発七ンタ一) 
HOT FAFERS

TIGG/09/02/89/HP-1

"A role of carbohydrate-carbohydrate interaction in the process of specific cell recognttion during embryogeneais and organogenesis: a preliminary note" Eggens, I.., Fenderson, B.A., Toyokuni, T., and Hokomori, S., BBRC 158 (1989) $913-920$

"Speciflc Interaction between $L e^{x}$ and Le $e^{x}$ determinants (A possible basis for cell recognition in preimplantation embryos and in embryonal carcinoma cella)" Eggens, I., Fenderson, B, Toyokund, T., Dean, B.., stroud, M., and Hakomori, S., JBC 264 (1989) 9476 9484

Carbohydrates on cell surface are believed to be involved in cell-cell interactions such as cellular recognition and cell attachment during embryogenisis and organogenesis. Recognition of carbohydrates by cell surface proteins such as endogenous lectins, glycosyltransferases, and glycosyl hydrolases has been implicated thus far. A new possibility that a specific carbohydrate on the cell surface could be recognized by the same carbohydrate on its cell surface counterpart is suggested by Hakomori and his associates based on the finding of specific interaction between $L \theta^{x}$ and $e^{x}$ determinants. According to their model, a specific interaction between two homotypic cells initially mediated by multiple carbohydrate-carbohydrate interactions is followed by interactions of pericellular adhesive proteins (fibronectin, vitronectin, thromboepondin, cadherin and so on), which eventually lead to a gap junction formation to establish a cell-cell communication channel.

(TCY)

TIGG/09/02/89/HP-2

"site specificity of the chorionic gonadotropin N-linked oligosaccharides in signal transduction"

Matzuk, M.M., Keane, J.L., and Boime, I., JBC 264 (1989) 2409-2414

Human chorionic gonadotropin (hCG) is a unique glycoprotein hormone in which $\underline{N}-1$ inked oligosacoharides have been belleved to be essential for the hormonal activity. Removal of all or part of the $N$-linked oligosaccharides on hCG by chemical or enzymatic treatments resulted in a decrease of its activity but less effect on its receptor binding. However, we have not been able to point out for sure which individual oligosaccharide(s) is involved in the hormonal activity thus far. Bolme and his associates have analyzed the role of $N$-linked oligosaccharides of hCG in receptor binding and signal transduction, using site-directed mutagenesis of hCG genes to produce hCG derivatives at individual glycosylation sites and their expression in Chinese hamster ovary cells. The absence of any or all of the hCG $\underline{N}-1$ inked oligosacchartdes had a minor effect on the receptor binding by the derivatives. But, the aboence of oligosaccharide at Asn-52 of alpha chain almost fully decreased both the steroidogenic and CAMP responses. Presence of other ollgosaccharides did not help at all. The use of site-directed mutagenesis was thus critical in revealing the role of the individual N-linked oligosaccharides on hCG. (TCY) 
TIGG/09/02/89/HP-3

"Sphingomyelinase action inhibits phorbol ester-induced differentiation of human promyelocytic leukemic (HL-60) cells"

Kolesnick, R.N., JBC 264 (1989) 7617-7623

"Free sphingosine formation from endogenous substrates by a liver plasma membrane system with a divalent cation dependence and a neutral pH optimum" Slife, C.W., Wang, E., Hunter, R., Wang, S., Burgess, C., Liotta, D., and Merrill, A.H.Jr.. JBC 264 (1989) 10371-10377

Protein kinase $C$ is a key enzyme in signal transduction in which 1,2-diacylglycerol acts as the physlologic activator of protein kinase C. Researchers have been looking for the natural negative effector( $\theta)$ for this enzyme. Bell and his associates suggested a possible involvement of free sphingosine (sphingoid bases) in an inhibitory pathway for protein kinase C (Science 235 (1987) 670-674). Kolesnick indicated that sphingomyelinase added to the cultured HL-60 cells inhibited phorbol ester-induced differentiation which was mediated via protein kinase $C$. The added enzyme sphingomyelinase was shown to increase the level of sphingoid bases which was sufficient to inactivate protein kinase $C$. This paper may imply the possible presence of a system by which sphingolipids (sphingomyelin, gangliosides, cerebrosides, etc), natural constituents of cells, are cleaved to produce sphingoid bases serving as endogenous modulators of cell functions. Slife et al. suggested that this was the case in a liver plasma membrane system where free long chain bases were formed from endogenous enzymes and substrates. (TCY) 